\title{
ADOPTION OF ICTS BY COMMUNICATION RESEARCHERS FOR SCIENTIFIC DIFFUSION AND DATA ANALYSIS
}

\section{Adopción de TIC por investigadores en comunicación para la difusión científica y el análisis de datos}

\section{Carlos Arcila-Calderón, Mabel Calderín and Ignacio Aguaded}

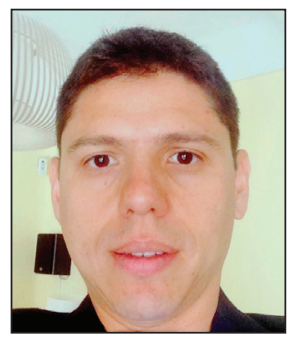

Carlos Arcila-Calderón, communications expert and researcher at the Universidad Rey Juan Carlos (URJC) (España), is editor of the Anuario electrónico de estudios en comunicación social "Disertaciones". European doctor in communication, social change, and development from the Universidad Complutense de Madrid, and master in journalism from the URJC. He has taught at the Universidad del Rosario (Colombia), Universidad del Norte (Colombia), Universidad de Los Andes (ULA) (Venezuela), and is a research associate at the Universidad Católica Andrés Bello (UCAB) (Venezuela). He has been a visiting professor at the Universidad Nacional de Educación a Distancia (UNED) (España), Universidad de la Sabana (Colombia), Universidad de Santiago de Compostela (Spain), and Universidade Estadual Paulista (Brasil). http://orcid.org/0000-0002-2636-2849

Universidad Rey Juan Carlos. Facultad de Ciencias de la Comunicación Camino del Molino, s/n. 28943 Fuenlabrada (Madrid). España carlos.arcila@urjc.es

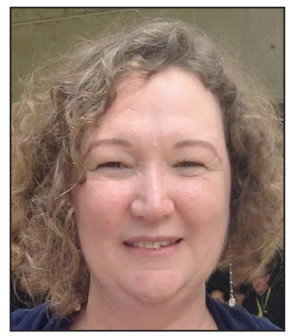

Mabel Calderín graduated in scientific and technical information and library science from the Universidad de La Habana. She is director of the Centro Cultural "Padre Carlos Guillermo Plaza S.J." and the Biblioteca Central of the Universidad Católica Andrés Bello (UCAB). Master of information systems at UCAB. Specialist on network management of information services units in the Universidad Central de Venezuela. Professor of the Escuela de Comunicación Social y del Postgrado in public sector management. Coordinator of Saber, the UCAB institutional repository. She is on the editorial board of the journal Temas de comunicación. Founding member of the Asociación de Investigadores Venezolanos de la Comunicación (InveCom). Cooperates and serves as a referee in national and international journal committees.

http://orcid.org/0000-0002-7750-4608

Universidad Católica Andrés Bello, Ccpcgp, Edif. Biblioteca Central Av. Teherán, Urb. Montalbán, La Vega, Aptdo. 20332, Caracas 1020, Venezuela mcalderi@ucab.edu.ve

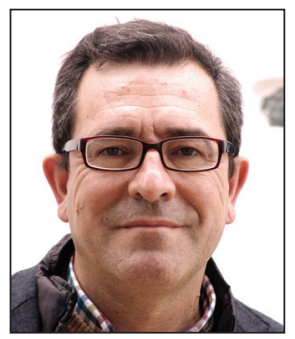

Ignacio Aguaded is a full professor of the Departamento de Educación of the Universidad de Huelva (Spain). President of Grupo Comunicar, veteran group in Spain carrying out research on edu-communication, and editor of the scientific journal Comunicar (indexed in WoS, Scopus, ERIH, Recyt...). He is director of Ágora research group, responsible for several national and international research projects, and has led numerous doctoral dissertations. He is director of the Master Internacional Interuniversitario de Comunicación y Educación Audiovisual (UNIA) UHU) and deputy director of the Programa interuniversitario de comunicación (US, UMA, UCA y $U H U)$. He has been vice-rector of technology, innovation, and quality of Universidad de Huelva for seven years (2005-12).

http://orcid.org/0000-0002-0229-1118

Universidad de Huelva, Facultad de Ciencias de la Educación Campus El Carmen, Av. Tres de Marzo, s/n. 21071 Huelva (Spain) aguaded@uhu.es

\section{Abstract}

This study examines the actual use of ICTs by communication and media researchers for scientific diffusion and data analysis. Survey data were collected from members of the International Communication Association (ICA) ( $\mathrm{n}=295)$. Adoption rate averages of most of the tools were close to the median, except for Twitter, grids, and simulation software. Consistent with 
past research and the Unified theory of acceptance and use of technology (Utaut), we found that performance expectancy is a predictor of adoption, though this relation was not moderated by age or gender. In the case of scholarly environments, we found that scientific collaboration is a stronger predictor of actual use. Theoretical and practical implications of the findings are discussed.

\section{Keywords}

ICT; Adoption of technology; Communication and media; Researchers; Performance expectancy; Scientific collaboration.

\section{Resumen}

Este estudio examina el uso que los investigadores en comunicación dan a las TIC para la difusión científica y el análisis de datos. Se reportan los datos de una encuesta a investigadores de la International Communication Association (ICA) (n=295). Las tasas de adopción de la mayoría de las herramientas consultadas se aproximaron a la mediana, salvo en los casos de Twitter, grids y software de simulación. Consistente con la investigación anterior y con la Teoría unificada de aceptación y uso de tecnologías (Utaut), encontramos que la expectativa de rendimiento es un predictor significativo de la adopción de TIC, aunque esta relación no está moderada ni por la edad ni por el género. En el caso de los contextos académicos, encontramos que la colaboración científica es el predictor más fuerte del uso de las TIC. Se discuten implicaciones teóricas y prácticas de los resultados.

\section{Palabras clave}

TIC; Adopción de tecnología; Comunicación; Investigadores; Expectativa de rendimiento; Colaboración científica.

Arcila-Calderón, Carlos; Calderín, Mabel; Aguaded, Ignacio (2015). Adoption of ICTs by communication researchers for scientific diffusion and data analysis. El profesional de la información, v. 24, n. 5, pp. 526-536.

http://dx.doi.org/10.3145/epi.2015.sep.03

\section{Introduction}

Contemporary science has increased the use of computers for knowledge discovery, but also for scientific diffusion and collaboration. In this context of e-Science (Hey; Trefethen, 2005; Nielsen, 2012) or e-research (Hey; Tansley; Tolle, 2009), the incorporation of information and communication technologies (ICTs) in scientific routines has affected the way scientists do their work (Borgman, 2007; Dutton, 2010). Scholars from fields such as physics have used e-tools intensively (Gentil-Beccott et al., 2009), but in the case of social sciences and the humanities this adoption process has been more heterogeneous and difficult (Arcila-Calderón; Said, 2012), even when in the last few years a set of techniques, tools and, dynamics have emerged within the so called digital humanities (Dutton; Jeffeys, eds., 2010; Sánchez; Romero, eds., 2014).

Commercial and non-commercial companies currently offer a wide range of e-tools that can be used in academic work (from specialized software and hardware to social media), and benefits from these ICTs can be related with the quantity and quality of research. In the first case, ICTs allow the production, analysis, curation, and sharing of huge amounts of information (known as big data) that may reconfigure the whole scientific activity (Hey; Tansley; Tolle, 2009). In the second case, these technologies permit an extraordinary capacity for collaboration, which has been related to the quality of the research processes (Liao, 2010; Rigby; Edler, 2005).

The e-tools may have an extensive number of specific uses, but in research environments these uses are focused on (i) scientific diffusion and (ii) scientific data analysis. Scientific diffusion refers to all messages created to communicate, facilitate, and articulate the scientific process. The way scientists communicate has been extensively studied and special attention has been paid to the influence of the Internet in this process (Gibbons et al., 1994; Briceño, 2014) in which non-specialized audiences have begun to participate (Waldrop, 2008; Neylon; Wu, 2009). On the other hand, data analysis includes all procedures used to gather, manage, compute, and store scientific information. In the era of big data, scientists are adopting software and platforms by which they are automatically obtaining millions of records, processing them, and then getting new knowledge directly from data (Zikopoulos et al., 2013; Kosciejew, 2013; Gobble, 2013; Mayer-Schonberger; Cukier, 2013). For example, the use of many computer-based methods to analyze content has been relevant in the field of social sciences and media studies (Leetaru, 2011; Verbeke et al., 2014; Pang; Lee, 2008; Lewis, Zamith; Hermida, 2013). Additionally, supported by universities and R\&D centers, scholars must deal with complex repositories, where they store, compute, and retrieve data.

Scholars of different fields adopt e-tools to a different degree and with different purposes. These differences may be caused by the specific dynamics, methods, and constraints of each discipline. The goal of this paper is to analyze how researchers in the field of communication and media studies adopt ICTs for their scientific work in special scientific diffusion and data analysis. In the sections that follow, we first provide an overview of past research and theoretical framework to address our research questions $(R Q)$ and hypotheses $(H)$. Then, we describe our method and report our findings.

\section{Adoption of ICTs by researchers}

There is an increasing interest in studying the adoption and use of ICTs by researchers in various disciplines (Pearce, 2010; Procter et al., 2010; Ponte; Simon, 2011; Dutton; Meyer, 2008; Briceño, Arcila-Calderón; Said, 2012; Arcila-Calderón, 
Piñuel; Calderín, 2013), given the consensus about the impact of these technologies on scientific methods and practices (Dutton, 2010; Hey; Trefethen, 2005; Borgman, 2007; Nielsen, 2012). Special attention has been paid to the adoption of web 2.0 tools given their current diffusion. Procter et al. (2010) collected information from 1,321 academics and doctoral students in the United Kingdom with the goal of detecting usage patterns of web 2.0 in the production and sharing of scientific content. According to the results, almost half of this sample (45\%) was classified as an occasional user, while frequent users only represented $13 \%$ of the sample and non-users reached $39 \%$. The data suggests that there is a significant correlation between the rate of adoption of these tools and the age, gender, and academic position of the researcher. Specifically, older males with higher-level academic posts were more inclined to use web 2.0 tools for research (i.e. Google Scholar, Wikipedia, Facebook, etc.). This study didn't find that young people or digital natives (Prensky, 2001) were the most extensive users of social tools in academic environments. On the contrary, it supports the results of the Education for change report (2012) that concludes that the new generation of researchers doesn't use digital technologies to their full potential.

There are differences between the parameters that regulate the adoption of ICTs orientated to data analysis and ICTS for scientific diffusion

But the fast spread of web 2.0 tools for scientific diffusion and interest towards ICTs for research is not consistent in all fields. Briceño; Arcila-Calderón; Said (2012) examined the habits of a community of high-energy particle physicists in Latin America. The results of their survey confirmed a trend of using traditional tools of electronic academic publication (arXiv and Spires) and other shared data management systems, but found a low level of interest in the use of web 2.0 tools (that are commercial, for mass and popular use) such as Facebook, blogs and Twitter, which serves as a reminder that each scientific discipline maintains distinct habits in the areas of scientific collaboration and communication. Nevertheless, Dutton and Meyer (2008) analyzed the attitudes of British social scientists towards e-research and technologies for scientific work through an online survey and found that within the different fields and methodological orientations that make up social sciences, there were no significant differences regarding interest towards e-research and ICTs.

Some studies suggest that there may be differences between the parameters that regulate the adoption of ICTS orientated to data analysis and ICTs for scientific diffusion (Pearce, 2010; Arcila-Calderón; Piñuel; Calderín, 2013). Pearce (2010) contributes empirical evidence of widespread use of web 2.0 tools for scientific diffusion (up to $43 \%$ ) among scholars in one British university (instant messengers, wikis, blogs). In the case of chats (instant messengers), there was a significant negative correlation in relation to age, which highlighted that older users demonstrated a lower probability of using chats. Similarly, even though not at a significant level, the same trend was identified in the use of blogs and wikis. On the other hand, the study found that gender could be positively correlated with the rate of adoption and knowledge of other advanced tools more orientated to data analysis and preservation (grids, repositories). That is, male researchers were more likely to discover and adopt tools such as the Access Grid (awareness of the existence of Access Grid nodes) and repositories (deposit any outputs in a repository such as ePrints). Thus, age might be related to the adoption of scientific diffusion tools and gender to the adoption of data analysis tools.

\section{Performance expectancy predicts beha- vioral intention of using and adopting ICTs}

To the best of our knowledge, there is no previous research that describes the way in which the international community of researchers in the area of communication and media studies adopts ICTs for their scientific work. However, a regional study demonstrated that Latin American scholars in this field have a positive attitude towards e-research and frequently use at least one basic e-tool, but there was evidence of a very limited use of advanced technologies (Arcila-Calderón; Piñuel; Calderín, 2013). According to these findings, adoption rates of ICTs for scientific diffusion were significant and about half of the researchers used tools such as chats $(41.14 \%)$, blogs (48.1\%), and social networks like Facebook and Twitter (62.34\%). The adoption of ICT orientated to data analysis was more heterogeneous. Some tools like simulation or web analysis software $(8.23 \%)$ and grids or clusters $(11.08 \%)$ had a low rate of adoption, and tools such as content analysis software (25.32\%), online survey software (38.92\%), tools for graphic visualization, management and creation (43.35\%), spreadsheets (44.62\%), and databases (57.91\%) were more spread among scholars. In order to extend this previous knowledge, we posed the following research question:

RQ1: To what extent does the international community of communication researchers adopt ICTs for scientific diffusion and data analysis?

\section{Performance expectancy through ICTs}

Previous studies have found a wide range of factors that might be related to ICT adoption (Williams et al., 2009; Zhang; Sun, 2009; Zhang; Aikman; Sun, 2008; Kaba; OseiBryson, 2013; Weber; Kauffman, 2011; Lal, 2008; Giunta; Trivieri, 2007) and several theoretical frameworks have been used to understand this process (Diffusion of innovations, Theory of reasoned action, Technological acceptance model - TAM, Motivational model, Planned behavior theory, PC use model, Social cognitive theory, etc.). To formulate the Unified theory of acceptance and use of technology (Utaut), Venkatesh; Morris; Davis; Davis (2003) reviewed eight theoretical models, which explained between 17 and 53 percent of the variance in user intentions to use information technology, and found that for every model construct 
related to performance expectancy (perceived usefulness, extrinsic motivation, relative advantage, job-fit, and outcome expectations) were always significant and also had the strongest influence. In Utaut performance expectancy is moderated by gender and age (the effect is stronger for younger individuals and for men) and is defined as the "degree to which an individual believes that using the system will help him or her to attain gains in job performance" (Venkatesh et al., 2003, p. 447). In a later revision of the model (Utaut2), Venkatesh; Thong; Xu (2012) kept performance expectancy as the strongest predictor of user intentions.

\section{There is not previous research that des-} cribes the way in which international community of researchers in the area of communication and media studies adopts ICTs for their scientific work.

Close constructs such as attitude toward using technology are also significant and relevant predictors in some models, but are not included either in Utaut or in Utaut2. In fact, there is no clear consensus whether attitudes act as determining factors in the adoption of the ICTs. According to Zhang, Aikman and Sun (2008) this controversy is due to the imprecision that has existed in studies in defining what an attitude is, for example without separating attitudes towards using ICT as an object (ATO) or towards using ICT as a behavior (ATB). In addition, the authors stated that it is necessary to include attitudes towards previous or similar versions of ICTs in the analysis, given that these are ultimately related to the intention of the behavior. Specifically, Zhang, Aikman and Sun (2008) carried out a survey of students from a North American university to evaluate their use and acceptance of a virtual learning environment (WebCT 6.0), and found that the ATB was a better predictor of the intention of the use of ICTs than the ATO. They also found that the effect of ATO was completely mediated by ATB. This operational distinction was maintained in later studies (Zhang; Sun, 2009), as well as other specific considerations in the structure of attitudes (if they incorporated experiential or instrumental aspects), which allowed for a better understanding and a predictive capacity of the models in which attitudes are considered as factors in the use and acceptance of the ICTs. However, the lack of consensus suggests that attitude towards using technology may be a problematic predictor

In line with Utaut and Utaut2 we posit that performance expectancy predicts adoption of ICTs for scientific work such that:

H1. Performance expectancy has a significant influence on actual use of ICTS.

And given the importance of variables gender and age we propose (as in Utaut and Utaut2) that they moderate the influence of performance expectancy on the adoption of ICTS for scientific work.

H2.1 The effect of performance expectancy on actual use of ICTs is moderated by age, such that the effect will be stronger for younger researchers.
H2.2 The effect of performance expectancy on actual use of ICTs is moderated by gender, such that the effect will be stronger for male researchers.

\section{Scientific collaboration}

Acknowledging the limitations of certain models, Weber; Kauffman (2011) state that the range of determinants is much wider (economic, social, and other factors), which is why it is evident that there isn't a clear consensus on the topic in scientific literature on ICT adoption. For instance, the analysis of Kaba; Osei-Bryson (2013), based on the results of a survey on the adoption and use of mobile telephones in Canada (Quebec) and Guinea (both French-speaking regions but with distinct cultural patterns), found factors that apparently determine the adoption of a technological innovation lose their effects in some environments. According to the data, in Canada the validity of models such as TAM (Technology acceptance model) was confirmed in which previous attitudes and perceptions (regarding usefulness and ease of use) are determinants in the adoption of ICTs. However in Guinea, these factors weren't significant.

It is therefore possible that certain specific factors are emerging. The study by Giunta and Trivieri (2007) showed that collaboration between companies (together with the size of the company, its geographical location, the functional composition of the workforce, the activities of R\&D, subcontracting and exports) was a highly significant determinant in the adoption of ICTs. In this sense, Lal (2008) found that among small and medium-sized companies in Malaysia with international technological collaboration there was a tendency to adopt more advanced ICTs. In academic contexts, scientific collaboration may affect scholarly practices (Cummings; Kiesler, 2005; Hara et al., 2003; Rigby; Edler, 2005; Liao, 2010). This is the case with the study previously mentioned by Procter et al. (2010), which found that greater scientific collaboration resulted from greater adoption of web 2.0 tools. Arcila-Calderón (2013) confirmed these results and found scientific collaboration was positively correlated with the adoption of ICTs by Latin American social researchers. Also, Bargak et al. (2010) found collaboration (together with funding and contribution to interesting research) was a catalyst that drove e-infrastructure adoption. These three previous studies suggested that in academic contexts the degree of scientific collaboration predicts ICT adoption. Thus our last hypothesis is:

H3. Scientific collaboration has a significant influence on actual use of ICTs.

\section{Adoption of ICTs by researchers for scientific work}

As we have seen in the previous sections, factors explaining ICT adoption are not always consistent. Nevertheless, Utaut and Utaut2 clearly show that performance expectancy is the strongest predictor of behavioral intention of ICT adoption in general contexts. In the case of academic and scientific environments, other relevant variables such as scientific collaboration should also be considered. Thus we suggest the sum of these two factors may explain the actual use of ICT for scientific work. Given their importance, we include gender and age 


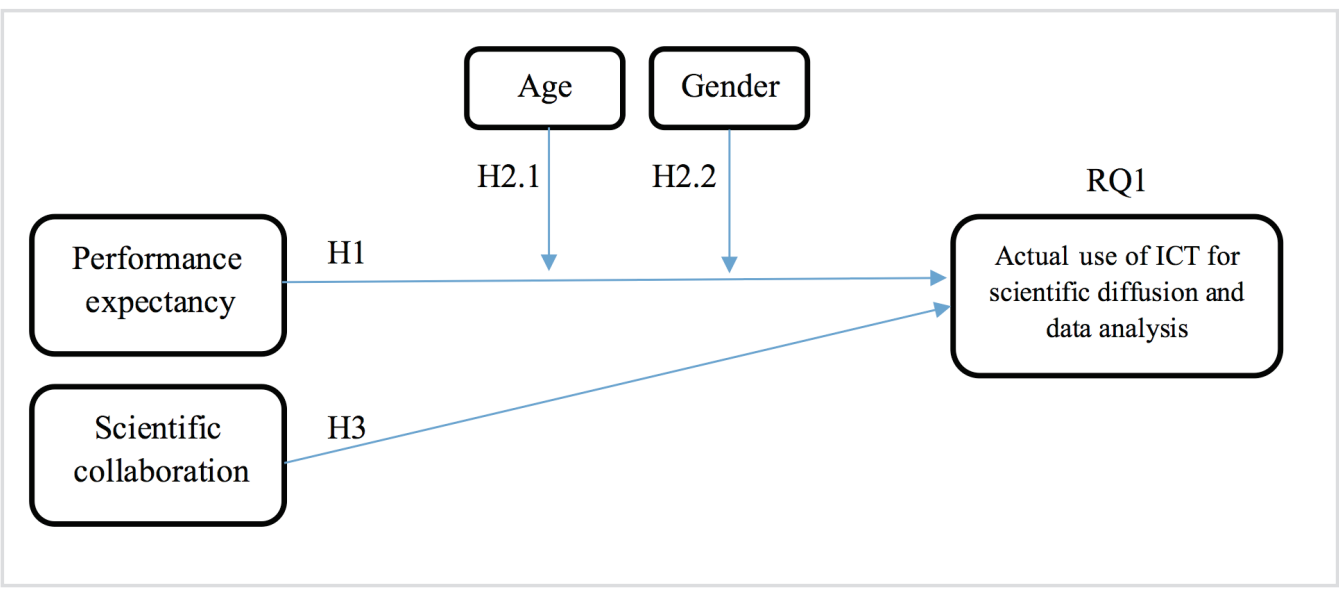

Figure 1. Theoretical model of adoption of ICTs for scientific work

as moderators of the influence of performance expectancy as they were included in Utaut and Utaut2. It is important to notice that although these models considered that performance expectancy predicts behavioral intention, we suggest this variable may directly predict actual use, which means there would not be a mediation process. Figure 1 shows our theoretical model, which includes performance expectancy (moderated by gender and age) and scientific collaboration as predictors of actual use of ICT for scientific work.

\section{Method}

\section{Participants and procedures}

Data were obtained from surveys administered to researchers affiliated to the International Communication Association (ICA), which is an international academic association for scholars in the field of communications and media studies. ICA is a prestigious well-known worldwide organization that promotes scientific diffusion and discussion in communication research, and active members are supposed to conduct and participate in investigations.

We randomly chose 400 ICA members (from a population of 1,812 active members openly registered by January 2013) and invited them to participate in the online survey from March 1 to July 31, 2013. A total of 348 answers were received, from which 295 were valid answers. The response rate was at $73,75 \%$, which represents a good rate but implies a self-selection bias. This limitation does not affect our findings since the goal was to describe processes rather than generalize our results (Shapiro, 2002). Although members belonged to more than 80 countries, the final version of the questionnaire was presented in English (translated from Spanish by authors and proofread by two experts). The survey was developed and executed using LimeSurvey software (hosted in university servers) and was designed to be completed in about 20 minutes.

\section{Measures}

The questionnaire was based on past research (Dutton; Meyer, 2008; Arcila-Calderón, 2013) and measures included: the type of e-tool used for sharing knowledge (actual use of ICT for scientific diffusion), the type of e-tool used for data analysis (actual use of ICT for data analysis), the benefits of ICTs for scientific tasks (performance expectancy), and the habits of collaborative work practices (scientific collaboration). Each item for actual use of ICT was measured with a dichotomous answer (0. No / 1. Yes) and constructs were summative (0-4 for actual use of ICT for scientific diffusion, 0-8 for actual use of ICT for data analysis and the sum of these two scales, 0-12 for actual use of ICT for scientific work). A 5-point Lickert scale, ranging from completely disagree (1) to completely agree (5), was used to measure items for performance expectancy (5-25 summative scale), and a 4-point scale, ranging from never (1) to very often (4), was used for scientific collaboration (4-16 summative scale).

Demographic variables were also included:

- age,

- gender ( $0=$ male, $1=$ female),

- region (1=Europe, 2=United States and Canada, 3=Latin America, 4=Africa, Asia the rest of the world),

- academic level (1=Bachelor's degree, 2=Master's, 3=Doctorate),

- main employment status (1=permanent teaching or researching, 2=postgraduate student, 3=non permanent teaching or researching), and

- specific area of research (ICA Division or Interest group).

Scientific collaboration was the strongest predictor of the model, being significant for both cases: actual use of ICTS for scientific diffusion and actual use of ICTs for scientific data analysis

Before the application of the questionnaire, we conducted a focus group of a panel of experts in order to assure content validity. Two independent researchers (not related with the study) assessed the instrument and made qualitative comments, which were considered to improve the questionnaire. Straightaway, we estimated test-retest reliability through the application of the survey to a group of 30 researchers in two different moments (with a gap of one week) to measure the correlations between the answers given on each occasion. Items that did not reach an intraclass correlation coefficient (ICC) of 0.70 were deleted or reconsidered ${ }^{1}$.

Once the data were collected, we assessed the validity of the constructs included in the questionnaire through an exploratory factorial analysis (EFA), which allows for the identification of underlying factors in a series of variables (PérezGil; Chacón; Moreno, 2000; Macía, 2010; Igartua, 2006). 
Items for each construct were factor analyzed with Varimax (orthogonal) rotation and EFA suggested a latent structure of four dimensions (table 1 ), explaining $52.93 \%$ of the variance for the set of 21 items and an examination of the Kaiser-Meyer Olkin measure of sampling adequacy suggested the sample was factorable (KMO=0.793). Performance expectancy (Factor 1) had an Eigen value of 4.371 and explained $20.82 \%$ of variance. Actual use of ICTs for scientific diffusion (Factor 2) had an Eigen value of 1.808 and explained $8.61 \%$ of variance. Actual use of ICTs for data analysis (Factor 3) had an Eigen value of 1.509 and explained 7.19\% of variance. And Scientific Collaboration (Factor 4) had an Eigen value of 1.328 and explained $6.32 \%$ of variance.

According to internal consistency reliability, Performance expectancy obtained $\alpha 0.755$, Actual use of ICTs for scientific diffusion was at $\alpha 0.674$, Actual use of ICTs for data analysis was at $\alpha 0.646$, and Scientific collaboration reached $\alpha 0.550$.
Although these last indicators didn't reach the ideal score of 0.70 (Cronbach, 1951; Hayes, 2005) in this ad hoc instrument, we decided to continue with their presence in the proposal given that they were very close to the minimum of 0.60 required for exploratory studies (Hair et al., 2000; Robinson; Shaver; Wrightsman, 1991).

\section{Analysis}

To address RQ1 we conducted descriptive analysis of data. In the case of $\mathrm{H} 1$ and $\mathrm{H} 3$, multiple linear regression analysis estimated by ordinary least squares (OLS) was carried out. We performed multicollinearity tests to check OLS assumptions and results showed tolerance values close to 1 and VIF values under 2 , which indicates the absence of multicollinearity (Cohen et al., 2003). To address H2.1 and H2.2, we ran a moderation analysis with SPSS Macro process (Model 2), developed by Hayes (2013).

Table 1. Loadings for exploratory factorial analysis (EFA) with Varimax rotation.

Note: Factor loadings $>0.400$ are in boldface.

\begin{tabular}{|c|c|c|c|c|}
\hline Item & 1 & 2 & 3 & 4 \\
\hline \multicolumn{5}{|l|}{ Performance expectancy } \\
\hline The use of digital technology in research is beneficial & 0.592 & 0.008 & 0.172 & 0.127 \\
\hline $\begin{array}{l}\text { e-Research (research based on ICT) positively affects my productivity and the productivity } \\
\text { of my research group }\end{array}$ & 0.702 & 0.007 & 0.147 & 0.206 \\
\hline $\begin{array}{l}\text { Reusing data and information from other scientists to produce new findings is an advan- } \\
\text { tage of collaborative work }\end{array}$ & 0.674 & 0.158 & 0.087 & -0.048 \\
\hline $\begin{array}{l}\text { The publication of content on free and open platforms increases the possibilities for col- } \\
\text { laboration between peers and / or research groups }\end{array}$ & 0.703 & 0.254 & -0.134 & 0.025 \\
\hline $\begin{array}{l}\text { e-Research (research based on ICT) facilitates the development of responses to the new } \\
\text { scientific questions that are appearing in my field of study }\end{array}$ & 0.697 & 0.191 & 0.050 & 0.173 \\
\hline \multicolumn{5}{|l|}{ Actual use of ICTs for scientific diffusion } \\
\hline I use chats & 0.223 & 0.469 & 0.158 & 0.124 \\
\hline I use Facebook & 0.068 & 0.746 & 0.087 & -0.002 \\
\hline I use Twitter & 0.091 & 0.736 & 0.149 & 0.017 \\
\hline I use blogs & 0.175 & 0.673 & 0.026 & 0.310 \\
\hline \multicolumn{5}{|l|}{ Actual use of ICTs for scientific data analysis } \\
\hline I use software for online surveys & 0.073 & -0.032 & 0.600 & -0.006 \\
\hline I use content analysis software (e.g. Atlas.ti) & 0.092 & 0.202 & 0.462 & -0.202 \\
\hline I use simulation or web analysis software (e.g. Netlogo) & -0.043 & 0.177 & 0.526 & -0.011 \\
\hline I use distributed computing systems (e.g. grid; cluster; cloud) & 0.123 & 0.361 & 0.420 & 0.091 \\
\hline I use digital storage sites & 0.140 & 0.311 & 0.477 & 0.147 \\
\hline I use databases & 0.138 & 0.063 & 0.424 & 0.310 \\
\hline I use tools for visualization, management and creation of graphics & 0.140 & 0.029 & 0.586 & 0.085 \\
\hline I use spreadsheets & -0.086 & -0.009 & 0.542 & 0.194 \\
\hline \multicolumn{5}{|l|}{ Scientific collaboration } \\
\hline $\begin{array}{l}\text { I have applied for national or international funding for a research project with peers that } \\
\text { belong to an institution that is different to me }\end{array}$ & 0.113 & -0.056 & -0.001 & 0.682 \\
\hline $\begin{array}{l}\text { I have sent my articles to a pre-print platform (an online platform where authors send and } \\
\text { publish articles before being published in a scientific journal) }\end{array}$ & 0.075 & 0.041 & -0.007 & 0.643 \\
\hline $\begin{array}{l}\text { I have used digital platforms to make public and share the raw data from my research (data- } \\
\text { bases, code books, procedure manuals, etc.) with the goal of third parties using them }\end{array}$ & 0.077 & 0.195 & 0.186 & 0.624 \\
\hline $\begin{array}{l}\text { I have participated in a virtual research community (working group or research network } \\
\text { with members based in a range of geographic locations with a method of working that } \\
\text { mainly takes place using the internet) }\end{array}$ & 0.103 & 0.228 & 0.122 & 0.530 \\
\hline
\end{tabular}




\section{Results}

Preliminary and descriptive results showed that researchers that answered the survey $(n=295)$ had an average age of 43.71 years $(S D=11,88)$ and in this sample there was a slightly higher percentage of men (54.1\%). Most of the individuals had completed a doctorate (76.6\%) and already had a permanent teaching or research position (72.9\%), which means that they are concentrated in scholarly contexts. Respondents were from all regions (Europe $=40.68 \%$, United States and Canada $=25.42 \%$, Latin America $=8.14 \%$ and Africa, Asia the rest of the world=25.76\%) and from all ICA Divisions and Interest groups, especially from Mass communication (14.9\%), Political communication (14.2\%), Communication and technology (12.2\%) and Journalism studies (9.5\%).

RQ1 was focused on the adoption rate of ICTS for scientific work by researchers. As exposed in the EFA, tools were classified into ICTS for scientific diffusion and ICTS for scientific data analysis. The rates of adoption (figure 2) for scientific diffusion among communication scholars were considerably more homogeneous (chats=41\%, Facebook $=42 \%$, Twitter $=28 \%$, blogs $=26 \%$ ) than those for scientific data analysis (software for online surveys $=70 \%$, content analysis software $=45 \%$, simulation or web analysis software $=7 \%$, distributed computing systems $=27 \%$, digital store sites $=44 \%$, databases $=44 \%$, tools for visualization, management and creation of graphics $=40 \%$, spreadsheets $=57 \%$ ). It is clear that researchers were familiar with ICTs for scientific diffusion, even when their adoption rates did not reach the $50 \%$. We can consider that, except for Twitter, all of these tools went through the take-off point, that is the point where it is difficult to stop the diffusion process (Rogers, 2003). In the case of ICTs for scientific data analysis, we found that simulation or web analysis software and distributed computing systems did not reach this take-off point, but tools such as software for online surveys and databases were widely spread.
On average, respondents had an actual use of almost half of the questioned ICTs for scientific work (0-12 scale, $M=5.28$, $\mathrm{SD}=2.83$ ). Both actual use of ICTS for scientific diffusion (0-4 scale, $\mathrm{M}=1.54, \mathrm{SD}=1.39)$ and actual use of ICTs for scientific data analysis (0-8 scale, $\mathrm{M}=3.75, \mathrm{SD}=1.96)$, had averages below the median but close to it. This implies that researchers have a medium level of adoption of ICTs and that there are not differences between the actual use for scientific diffusion and scientific data analysis $[t(266)=-0.114,>0.05]$ (using z-scores).

To test our model we carried out regression and moderation analyses (table 2). The regression was significant $[F(6$, $221)=12.32, p<0.001]$ and included predictors in the model which explained $25 \%\left(R^{2}=0.25\right)$ of the variance $\left(f^{2}=0.33\right.$; medium effect size, according to Cohen, 1988) of actual use of ICT for scientific work (23\% in the case of actual use of ICTS for scientific diffusion and $15 \%$ in the case of actual use of ICTS for scientific data analyis). We found that performance expectancy ( $5-25$ scale, $\mathrm{M}=16.43, \mathrm{SD}=2.33$ ) was a significant predictor on actual use of ICT for scientific work ( $b=0.31$, $<0.001$ ) which clearly supports $\mathrm{H} 1$. This predictor was significant with actual use of ICTs for scientific diffusion ( $b=0.16$, $<0.001$ ) as well as actual use of ICTs for scientific data analyis $(b=0.15,<0.01)$. Instead, we found that age $(b=0.00,>0.05)$ and gender $(b=0.27,>0.05)$ did not moderate the influence of performance expectancy on actual use of ICT for scientific work, thus $\mathrm{H} 2.1$ and $\mathrm{H} 2.2$ were not supported, as suggested by Utaut ${ }^{2}$. However, the analysis revealed that age was a predictor for actual use of ICTS for scientific diffusion ( $b=-$ $0.02,<0.01$ ) but was not for actual use of ICTs for scientific data analyis $(b=-0.01,>0.05)$, which means that younger researchers will adopt more tools such as chats, Facebook, Twitter, and blogs.

Scientific collaboration (4-16 scale, $M=4.52, S D=1.45$ ) was the strongest predictor of the model $(b=0.69,<0.001)$, being significant for both cases: actual use of ICTs for scientific diffusion $(b=0.30$, $<0.001$ ) and actual use of ICTs for scientific data analyis $(b=0.38,>0.01)$. This result fully supports $\mathrm{H} 3$ and suggests that in academic contexts collaboration practices are determinants in the adoption of ICTs for both scientific diffusion and data analysis.

\section{Discussion and conclusion}

The goal of this study was to describe the actual use of ICTs by communication and media researchers. Consistent with past research (Procter et al., 2010; Pearce, 2010; Arcila-Calderón; Piñuel; Calderín, 2013), we found that, except for Twitter, communication scholars have an adoption rate of chats, Facebook and blogs close to $50 \%$. This indicates that web 2.0 tools for scientific diffusion are commonly used or at least there is a medium level of adoption. The case of Twitter is particular since only $28 \%$ of researches have adopted it. 
Table 2. Multiple linear regression and moderation analysis to test $\mathrm{H} 1, \mathrm{H} 2.1, \mathrm{H} 2.2$ and $\mathrm{H} 3$

\begin{tabular}{|c|c|c|c|}
\hline \multicolumn{4}{|c|}{ ICT adoption by communication researchers } \\
\hline & $\begin{array}{c}\text { Actual use of ICT for scientific } \\
\text { diffusion }\end{array}$ & $\begin{array}{c}\text { Actual use of ICT for scientific data } \\
\text { analysis }\end{array}$ & $\begin{array}{l}\text { Actual use of ICT for scientific } \\
\text { work (diffusion + data analysis) }\end{array}$ \\
\hline & $\mathrm{b}$ & $\mathrm{b}$ & $\mathrm{b}$ \\
\hline Performance expectancy & $0.16^{* * *}$ & $0.15^{* *}$ & $0.31^{* * *}$ \\
\hline Scientific collaboration & $0.30 * * *$ & $0.38^{* *}$ & $0.69 * * *$ \\
\hline Gender & 0.07 & -0.04 & 0.09 \\
\hline Age & $-0.02^{* *}$ & -0.01 & $-0.03^{*}$ \\
\hline Performance expectancy x Gender & 0.10 & 0.19 & 0.27 \\
\hline Performance expectancy x Age & -0.00 & 0.00 & 0.00 \\
\hline Adjusted $R^{2}$ & 0.23 & 0.15 & 0.25 \\
\hline Anova & $F(6,230)=11.67^{* * *}$ & $F(6,225)=6.43^{* * *}$ & $F(6,221)=12.32^{* * *}$ \\
\hline
\end{tabular}

${ }^{*} p<0.05 ;{ }^{*} p<0.01 ; * * *<<0.001$.

In contrast with recent reports (Education for change report, 2012), data also shows that scientific diffusion through ICTs is becoming important for younger researchers, which suggests that it is still necessary to promote these tools among more experienced scholars. On the other hand, age was not a predictor of actual use of ICTs for scientific data analysis, meaning that researchers of all ages adopt these tools to the same extent. Within this set of tools, ICTs such as simulation software or grids did not reach the take-off point. These tools are probably much more frequent in natural and experimental sciences because of their approaches. For the case of distributed computing systems we infer that communication research has not sufficiently adopted "big science" dynamics, which includes computing big data and articulating huge research teams, for which grids are ideal platforms. Nonetheless, other ICTs for scientific data analysis seem to have spread $(>40 \%)$, which would mean that researchers are related to computer-based discovery.

Because of the self-selection bias in the sample, we cannot draw conclusive remarks or generalize adoption rates. However, our data clearly shows that many researchers are aware of transformations in scientific practices based on ICT. This is crucial since early adopters and local experts finally motivate others within the same field to use technologies (Stewart, 2007). Further research is needed to compare actual use of ICT among different scientific communities and also among divisions within a community. In our study we did not analyze differences among ICA divisions or interest groups (or between qualitative and quantitative researchers), but there might be disparities.

Our results provide support to the finding that performance expectancy predicts actual use of ICT (Venkatesh et al., 2003; Venkatesh, Thong; Xu, 2012). This perceived usefulness (Davis, Bagozzi; Warshaw, 1992; Davis, 1989) is a clear determinant in ICT adoption, which means that individual beliefs about technologies have a strong importance in the decision process. In our case, these expectancies are especially related to the future scientific productivity and the generation of new findings, thus researchers believing new technologies may help with scientific discovery will be more likely to adopt them. Our findings also suggest that age and gender do not moderate the effect of performance expec- tancy on actual use of ICTS. This fact has some theoretical implications. First, our study differs from Utuat (Venkatesh et al., 2003) and Utaut2 (Venkatesh, Thong; Xu, 2012), meaning that in an academic context these variables may not moderate this relationship, due to the specific dynamics of research processes. Instead, as discussed earlier, age could have a direct effect on actual use of some social ICTs. On the other hand, our proposed model shall eliminate these two moderation variables, and include age as a predictor.

We suggest that specific models must be explored to understand ICT adoption for scientific work, due to the particular constraints of scholar contexts

Scientific collaboration was the strongest predictor of our model, which is consistent with past research focused on ICT adoption by researchers (Procter et al., 2010; Bargak et al., 2010; Arcila-Calderón, 2013). It is evident that collaboration actions and dynamics require appropriated tools and sometimes advanced digital platforms. A good example of this is the Large Hadron Collider, for which more than 3,000 physicists work and collaborate using sophisticated grids to store, share and compute data. But this project is also a good example of ICT adoption for scientific diffusion since some experiments (i.e. Atlas) can be followed through Twitter or Facebook. The average collaboration index in our sample of communication scholars was low, which can explain why the grids also had a low adoption rate. Therefore, the inclusion of collaboration as a predictor of ICT adoption in scientific environments may help to increase the explained variance of theoretical models in future research. We need to point out some limitations concerning this variable. First, the internal consistency of this construct was modest $(\alpha 0.550)$, which can be caused by the few number of items in this scale. Second, other indicators that were not included in this study (such as co-authorship) might be considered in order to measure collaboration.

Utaut2 explained up to $52 \%$ of the variance for actual use and up to $74 \%$ of the variance for behavioral intention 
(Venkatesh, Thong; Xu, 2012). Our proposed model only explained $25 \%$ of variance for actual use of ICT, thus other predictors might be included. These determinants may be in line with Utaut2 (effort expectancy, social influence, facilitating conditions, hedonic motivation, price value, habit), but we consider that other specific predictors should arise for scientific and scholarly contexts (institution size, research approach, cultural dynamics). To some extent, our findings suggest that specific models must be explored to understand ICT adoption for scientific work, due to the particular constraints of scholar contexts.

In summary, this study describes actual use of ICT for scientific work of communication scholars and gives some insight about the determinants that influence the adoption decision. This study provides empirical evidence to support performance expectancy as an important predictor in ICT adoption but proposes to include scientific collaboration as a determinant in scientific and scholarly environments. Future research may replicate this survey in other disciplines and contexts with larger samples. However, in our study power analysis indicated that sample size was adequate. Specifically, sensitivity analysis using G*Power 3.1.9.2 (Faul, Erdfelder, Lang; Buchner, 2007; Faul, Erdfelder, Buchner; Lang, 2009), determined the magnitude of effect that could be detected with 295 individuals (assuming 1-B=0.80), finding that our sample was large enough to identify a small effect size of 0.03 (Cohen, 1988).

In terms of practical implications, our study suggests that sensitization campaigns might be appropriated to increase performance expectancies among researchers, informing the benefits of ICT use in research. Campaigns can be accompanied by direct education to local experts and leaders in computedbased discovery, thus they can promote ICT use within the particular field. In addition, funding programs and scholarly accreditations might promote scientific collaboration through international calls and co-authorship recognition, respectively. As earlier discussed, this kind of collaboration significantly increases ICT use for scientific discovery and diffusion.

\section{Notes}

1. Inconsistencies were found in answers on the use of commercial video conferencing tools (Skype) and advanced video conferencing tools (e.g. Internet2), which is why they were deleted from items. In the case of social media, the original variable asked about the use of "Facebook and Twitter" jointly, but after inconsistencies occurred, the research team decided to separate these items and measure them independently.

2. To expand these findings we ran a moderated moderation analysis (Hayes, 2013) to test three-way interaction within Performance expectancy $\mathrm{x}$ Age $\mathrm{x}$ Gender. This analysis allows determining whether the moderation of Performance expectancy's effect on Actual use of ICTS for scientific work moderated by age is itself moderated by gender. Using SPSS Macro process (Model 3) we found that the regression was significant $[F(8,219)=9.20, p<0.001]$ explainig $25 \%$ of the variance, but without any moderation interactions. When running this analysis the only significant predictor was Scientific collaboration $(b=0.70,<0.001)$ and Performance expectancy did not show a clear influence $(b=0.15,>0.05)$.

\section{Acknowledgments}

This research received funding from the Latin American Council for Social Sciences (Clacso). The authors express their gratitude to Andreína Arcila and Eduar Barbosa for their participation in data collection and analysis.

\section{References}

Arcila-Calderón, Carlos (2013). e-Investigación en ciencias sociales [Report]. Buenos Aires: Clacso.

Arcila-Calderón, Carlos; Calderín, Mabel; Nuñez, Luis; Briceño, Ysabel (2013). "E-research: the new paradigm of science in Latin America”. In: Arcila-Calderón, Calderín \& Castro (eds.). An overview to digital media in Latin America, pp. 38-51. London: University of West London. ISBN: 9789802447282

Arcila-Calderón, Carlos; Piñuel, José; Calderín, Mabel (2013). "e-research on media and communication studies". Comunicar: Revista científica de comunicación y educación, marzo, n. 40, pp. 111-118.

http://dx.doi.org/10.3916/C40-2013-03-01

Arcila-Calderón, Carlos; Said-Hung, Elias (2012). “Factores que inciden en la variación de seguidores en los usuarios top20 más vistos en Twitter en América Latina y Medio Oriente". Interciencia, v. 37, n. 12, pp. 875-882.

http://www.redalyc.org/articulo.oa?id=33925592003

Borgman, Christine (2007). "Data: input and output of scholarship". In: Borgman (ed.), Scholarship in the digital age. Information, infrastructure, and the internet, pp. 115-148. Cambridge, Massachusetts: MIT Press. ISBN: 9780262026192

Briceño, Ysabel (2014). El modo emergente de la comunicación de la ciencia: incidencias y gestión distribuida en América Latina (Unpublished doctoral dissertation). Universidad de los Andes, Mérida, Venezuela.

Briceño, Ysabel; Arcila-Calderón, Carlos; Said-Hung, Elias (2012). "Colaboración y comunicación científica en la comunidad latinoamericana de físicos de altas energías". e-Colabora. Revista de ciencia, educación, innovación y cultura apoyadas por redes de tecnología avanzada, v. 2, n. 4, pp. 106-117.

http://publicaciones.renata.edu.co/index.php/RCEC

Cohen, Jacob (1988). Statistical power analysis for the behavioral sciences ( $2^{\text {nd }}$ ed.). Hillsdale, NJ: Erlbaum. ISBN: 978 0805802832

Cohen, Jacob; Cohen, Patricia; West, Stephen G.; Aiken, Leona S. (2003). Applied multiple regression/correlation analysis for the behavioral sciences ( $3^{\text {rd }}$ ed.). Mahwah, NJ: Erlbaum. ISBN: 9780805822236

Cummings, Jonathon N.; Kiesler, Sara (2005). "Collaborative research across disciplinary and organizational boundaries". Social studies of science, v. 35, n. 5, pp. 703-722. http://dx.doi.org/10.1177/0306312705055535

Davis, Fred D. (1989). "Perceived usefulness, perceived ease of use, and user acceptance of information technology". MIS quarterly, v. 13, n. 3, pp. 319-339.

http://dx.doi.org/10.2307/249008 
Davis, Fred D.; Bagozzi, Richard P.; Warshaw, Paul R. (1992).

"Extrinsic and intrinsic motivation to use computers in the workplace". Journal of applied social psychology, v. 22, n. 14, pp. 1111-1132.

http://dx.doi.org/10.1111/j.1559-1816.1992.tb00945.x

Dutton, William (2010). "Reconfiguring access in research: information, expertise, and experience". In: W. Dutton; P. Jeffreys (eds.). World wide research. Reshaping the sciences and humanities, pp. 1-19. Cambridge, Massachusetts: MIT Press. ISBN: 9780262014397

Dutton, William; Jeffeys, Paul (eds.) (2010). World wide research. Reshaping the sciences and humanities. Cambridge, Massachusetts: MIT Press. ISBN: 9780262014397

Dutton, William; Meyer, Erick T. (2008). “E-social science as an experience technology: Distance from, and attitudes toward, e-research". In: $4^{\text {th }}$ Intl conf on e-social science. http://www.ncess.ac.uk/events/conference/programme/ thurs/1bMeyerb.pdf

Education for change (2012). Researchers of tomorrow. The research behavior of generation $Y$ doctoral students [Report]. http://www.jisc.ac.uk/publications/reports/2012/researchersof-tomorrow

Faul, Franz; Erdfelder, Edgar; Buchner, Axel; Lang, AlbertGeorg (2009). "Statistical power analysis using G*Power 3.1: Tests for correlation and regression analysis". Behavior research methods, v. 41, n. 4, pp. 1149-1160.

http://dx.doi.org/10.3758/BRM.41.4.1149

Faul, Franz; Erdfelder, Edgar; Lang, Aalbert-Georg; Buchner, Axel (2007). "G*Power 3: A flexible statistical power analysis program for the social, behavioral, and biomedical sciences". Behavior research methods, v. 39, n. 2, pp. 175-191. http://dx.doi.org/10.3758/BF03193146

Gentil-Beccot, Anne; Mele, Salvatore; Holtkamp, Annette; O'Connell, Heath; Brooks, Travis (2009). "Information resources in high-energy physics: Surveying the present landscape and charting the future course". Journal of the American Society for Information Science and Technology, v. 60, n. 1, pp. 150-160.

http://dx.doi.org/10.1002/asi.20944

Gibbons, Michael; Limoges, Camile; Nowotny, Helga; Schwartzman, Simon; Scott, Peter; Trow, Martin (1994). The new production of knowledge: The dynamics of science and research in contemporary societies. London: Thousand Oaks; New Delhi: Sage. ISBN: 9780803977945

Giunta, Anna; Trivieri, Francesco (2007). “Understanding the determinants of information technology adoption: evidence from Italian manufacturing firms". Applied economics, v. 39, n. 10-12, pp. 1325-1334.

http://dx.doi.org/10.1080/00036840600567678

Gobble, MaryAnne M. (2013). "Big data: The next big thing in innovation". Research-technology management, v. 56, n. 1, pp. 64-66.

http://dx.doi.org/10.5437/08956308X5601005

Hair, Joseph; Anderson, Rolph; Tatham, Ronald; Black, WiIliam (1999). Análisis multivariante ( $5^{\text {th }}$ ed.). Madrid: Prentice Hall International. ISBN: 9788483220351
Hara, Noriko; Solomon, Paul; Kim, Seung-Lye; Sonnenwald, Diane H. (2003). "An emerging view of scientific collaboration: Scientists' perspectives on collaboration and factors that impact collaboration". Journal of the American Society for Information Science and Technology, v. 54, n. 10, pp. 952-965.

http://dx.doi.org/10.1002/asi.10291

Hayes, Andrew (2005). Statistical methods for communication science. Mahwah, NJ: Lawrence Erlbaum Associates. ISBN: 9780805854879

Hayes, Andrew (2013). Introduction to mediation, moderation, and conditional process analysis: A regressionbased approach. New York: Guilford Press. ISBN: 978 1609182304

Hey, Tony; Tansley, Stewart; Tolle, Kristin (2009). "Jim Gray on e-science: A transformed scientific method" In: Hey, T., Tansley, S.; Tolle, K. (Eds.). The fourth paradigm. Data-intensive scientific discovery, pp. xvii-xxxi. Redmond, Washington: Microsoft Research. ISBN: 9780982544204

Hey, Tony; Trefethen, Anne (2005). "Cyberinfrastructure for e-science". Science, v. 308, n. 5723, pp. 817-821. http://dx.doi.org/10.1126/science.1110410

Igartua, Juan (2006). Métodos cuantitativos de investigación en comunicación. Barcelona: Bosch. ISBN: 9788497902717

Kaba, Bangaly; Osei-Bryson, Kweku-Muata (2013). "Examining influence of national culture on individuals' attitude and use of information and communication technology: Assessment of moderating effect of culture through cross countries study". International journal of information management, v. 33, n. 3, pp. 441-452.

http://dx.doi.org/10.1016/j.ijinfomgt.2013.01.010

Kosciejew, Marc (2013). "The era of big data" Feliciter, v. 59, n. 4, pp. 52-55.

Lal, Kaushalesh (2008). "Information and communication technology adoption in Malaysian SMEs". Asian journal of technology innovation, v. 16, n. 1, pp. 161-186.

http://dx.doi.org/10.1080/19761597.2008.9668652

Leetaru, Kalev (2011). Data mining methods for the content analyst: An introduction to the computational analysis of informational center. New York: Routledge. ISBN: 978 0415895149

Lewis, Seth; Zamith, Rodrigo; Hermida, Alfred (2013). "Content analysis in an era of big data: A hybrid approach to computational and manual methods". Journal of broadcasting \& electronic media, v. 57, n. 1, pp. 34-52.

http://dx.doi.org/10.1080/08838151.2012.761702

Liao, Chien (2010). "How to improve research quality? Examining the impacts of collaboration intensity and member diversity in collaboration networks". Scientometrics, v. 86, pp. 747-761.

http://dx.doi.org/10.1007/s11192-010-0309-2

Macía-Sepúlveda, Felipe (2010). "Validez de los tests y el análisis factorial: nociones generales". Ciencia y trabajo, v. 12, n. 35, pp. 276-280.

http://www.cienciaytrabajo.cl/pdfs/35/pagina276.pdf 
Mayer-Schonberger, Viktor; Cukier, Kenneth (2013). Big data: A revolution that will change how we live, work and think. London: John Murray. ISBN: 9780544227750

Neylon, Cameron; Wu, Shirley (2009). “Open science: Tools, approaches, and implications". In: XIV Pacific symposium on biocomputing.

http://psb.stanford.edu/psb-online/proceedings/psb09/ workshop-opensci.pdf

Nielsen, Michael (2012). "Reinventing discover" In: Reinventing discovery: The new era of networked science. New Jersey: Princeton University Press. ISBN: 9780691148908

Pang, Bo; Lee, Lillian (2008). “Opinion mining and sentiment analysis". Foundations and trends in information retrieval, v. 2, n. 1-2, pp. 1-135.

http://dx.doi.org/10.1561/1500000011

Pearce, Nick (2010). "A study of technology adoption by researchers. Web and e-science infrastructures to enhance research". Information, communication \& society, v. 13, n. 8 , pp. 1191-1206.

http://dx.doi.org/10.1080/13691181003663601

Pérez-Gil, José; Chacón, Salvador; Moreno, Rafael (2000). "Validez de constructo: el uso de análisis factorial exploratorio-confirmatorio para obtener evidencias de validez". Psicothema, v. 12 , supl. n. 2, pp. 442-446.

http://www.psicothema.com/pdf/601.pdf

Ponte, Diego; Simon, Judith (2011). "Scholarly communication 2.0: Exploring researchers' opinions on web 2.0 for scientific knowledge creation, evaluation and dissemination". Serials review, v. 37, n. 3, pp. 149-156.

http://dx.doi.org/10.1080/00987913.2011.10765376

Prensky, Mark (2001). "Digital natives, digital immigrants". On the horizon, v. 9, n. 5, pp. 1-6.

http://dx.doi.org/10.1108/10748120110424816

Procter, Rob; Williams, Robin; Stewart, James; Proschen, Meik; Snee, Helene; Voss, Alex; Asgari-Targhi, Marzieh (2010). "Adoption and use of web 2.0 in scholarly communications". Philosophical transactions of the Royal Society AMathematical physical, n. 368, pp. 4.029-4.056 http://dx.doi.org/10.1098/rsta.2010.0155

Rigby, John; Edler, Jakob (2005). "Peering inside research networks: Some observation on the effect of the intensity of collaboration on the variability of research quality". Research policy, n. 34, pp. 784-794.

http://dx.doi.org/10.1016/j.respol.2005.02.004

Robinson, John P.; Shaver, Phillip R.; Wrightsman, Lawrence S. (1991). "Criteria for scale selection and evaluation". In: J. Robinson; P. Shaver; L. Wrightsman (eds.). Measures of personality and social psychological attitudes, pp. 1-16. San Diego: Academic Press. ISBN: 9780125902441

Rogers, Everett (2003). Diffusion of innovations. New York: Free Press. ISBN: 9780743222099

Sánchez, Esteban; Romero, María (Eds.) (2014). Ciencias sociales y humanidades digitales: técnicas, herramientas y herramientas de e-research e investigación en colaboración. La Laguna: Cuadernos artesanos de Latina, 61. ISBN: 97884 15698647

Shapiro, Michael (2002). "Generalizability in communication research". Human communication research, v. 28, n. 4, pp. 491-500.

http://dx.doi.org/10.1111/j.1468-2958.2002.tb00819.x

Stewart, James (2007). "Local experts in the domestication of information and communication technologies". Information, communication \& society, v. 10, n. 4, pp. 547-569. http://dx.doi.org/10.1080/13691180701560093

Venkatesh, Viswanath; Morris, Michael; Davis, Gordon; Davis, Fred (2003). "User acceptance of information technology: Toward a unified view". MIS quarterly, v. 27, n. 3, pp. 425-478.

http://www.jstor.org/stable/30036540

Venkatesh, Viswanath; Thong, James; Xu, Xin (2012). "Consumer acceptance and use of information technology: Extending the unified theory of acceptance and use of technology". MIS quarterly, v. 36, n. 1, pp. 157-178 http://dx.doi.org/10.1109/TEM.2010.2058851

Verbeke, Mathias; Berendt, Bettina; d'Haenens, Leen; Opgenhaffen, Michaël (2014). "When two disciplines meet, data mining for communication science" In: $64^{\text {th }}$ Annual ICA conference.

https://lirias.kuleuven.be/handle/123456789/436424

Waldrop, Mitchell (2008). "Science 2.0. Is open access science the future? Is posting raw results online, for all to see, a great tool or a great risk?" Scientific American, April 21.

http://www.scientificamerican.com/article/science-2-point-0

Weber, David; Kauffman, Robert (2011). "What drives global ICT adoption? Analysis and research directions". Electronic commerce research and applications, v. 10, n. 6, pp. 683-701. http://dx.doi.org/10.1016/j.elerap.2011.01.001

Williams, Michael; Dwivedi, Yogesh; Lal, Banita; Schwarz, Andrew (2009). "Contemporary trends and issues in IT adoption and diffusion research". Journal of information technology, n. 24, pp. 1-10.

http://dx.doi.org/10.1057/jit.2008.30

Zhang, Ping, Aikman, Shelley; Sun, Heshan (2008). "Two types of attitudes in ICT acceptance and use". Intl journal of human-computer interaction, v. 24, n. 7, pp. 628-648.

http://dx.doi.org/10.1080/10447310802335482

Zhang, Ping; Sun, Heshan (2009). "The complexity of different types of attitudes in initial and continued ICT use". Journal of the American Society for Information Science and Technology, v. 60, n. 10, pp. 2048-2063.

http://dx.doi.org/10.1002/asi.21116

Zikopoulos, Paul; DeRoos, Dirk; Parasuraman, Krishnan; Deutsch, Thomas; Giles, James; Corrigan, David (2013). Harness the power of big data. New York: McGraw-Hill. ISBN: 9780071808170 